\title{
The Employment Act of 1946: Some History Notes
}

\section{G. J. Santoni}

Thus, because of the planlessness of the wenties - because of the lack of courageous action immediately following the collapse - the nation lost 105,000,000 man-years of production in the thirties.

\author{
- Full Employment Act of 1945, Hearings, p. 1104
}

BOUT 40 years ago, in response to the Depression of the 1930s, Congress passed the Employment Act of 1946. Its sponsors believed that earlier failures to deal with massive worldwide unemployment had contributed significantly to the rise of National Socialism, which eventually culminated in World War II. 'This belief urged the act's sponsors to find a solution to the problem that had caused "such a great melting away of prosperity in such a short period of time."t

The legislation followed on the heels of a revolution in macroeconomic theory. 'This new theory suggested that periodic booms and busts could be avoided if govermment pursued a policy of "compensatory finance." The new theory promised the success of centrally directed economic stabilization policy and provided the nucleus around which the proposed legislation was built.

The bill that was initially proposed stired up considerable controversy. Some considered it "a great Magna Carta of government planning for full employ" ment." Others viewed it as "utterly alien to America

G. 4 Santoni is a senior economist at the Federal Resenve Bank of St. Lous. Thomas A. Polmann provided research assistance.

Full Employment Act of 1945 (1945), p. 1110.

'Hansen (1956), p. 97. and her institutions." Over the intervening years, discussions of the Employment Act have becone less shrill, but we continue to regard unemployment as an important problem. The purpose of this paper is to place this policy concern in its historical context as it initially surfaced in congressional debates of the Full Employment Bill of 1945 and as it re-emerged in debates of the Full Employment and Balanced Growth Bitll of 1976.

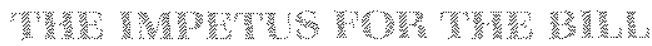

Chart 1 plots the unemployment rate from $1900-40{ }^{4}$ Before 1930 , the unemployment rate moved around an average of about 4.5 percent. Beginning that year, however, it rose substantially, reaching 25 percent of

\footnotetext{
${ }^{3}$ Full Employment Act of 1945 (1945), p. 1138.

4The data are from Historical Statistics of the United States Colonial Times to 1970 (1975), pp. 122-23 and p. 126. Measurement, of course, is never perfect. These unemployment data are based on estimates of Lebergott (1957); and Romer (1986) suggests they are relatively noisy. Furthermore, Darby (1976) argues that these data tend to overstate unemployment after 1933 because Federal Emergency Workers (employees of the Civilian Conservation Corps, National Youth Administration, Civil Works Administration and the Works Progress Administration) were counted as unemployed.
} 
Chart 1

\section{Unemployment Rate}

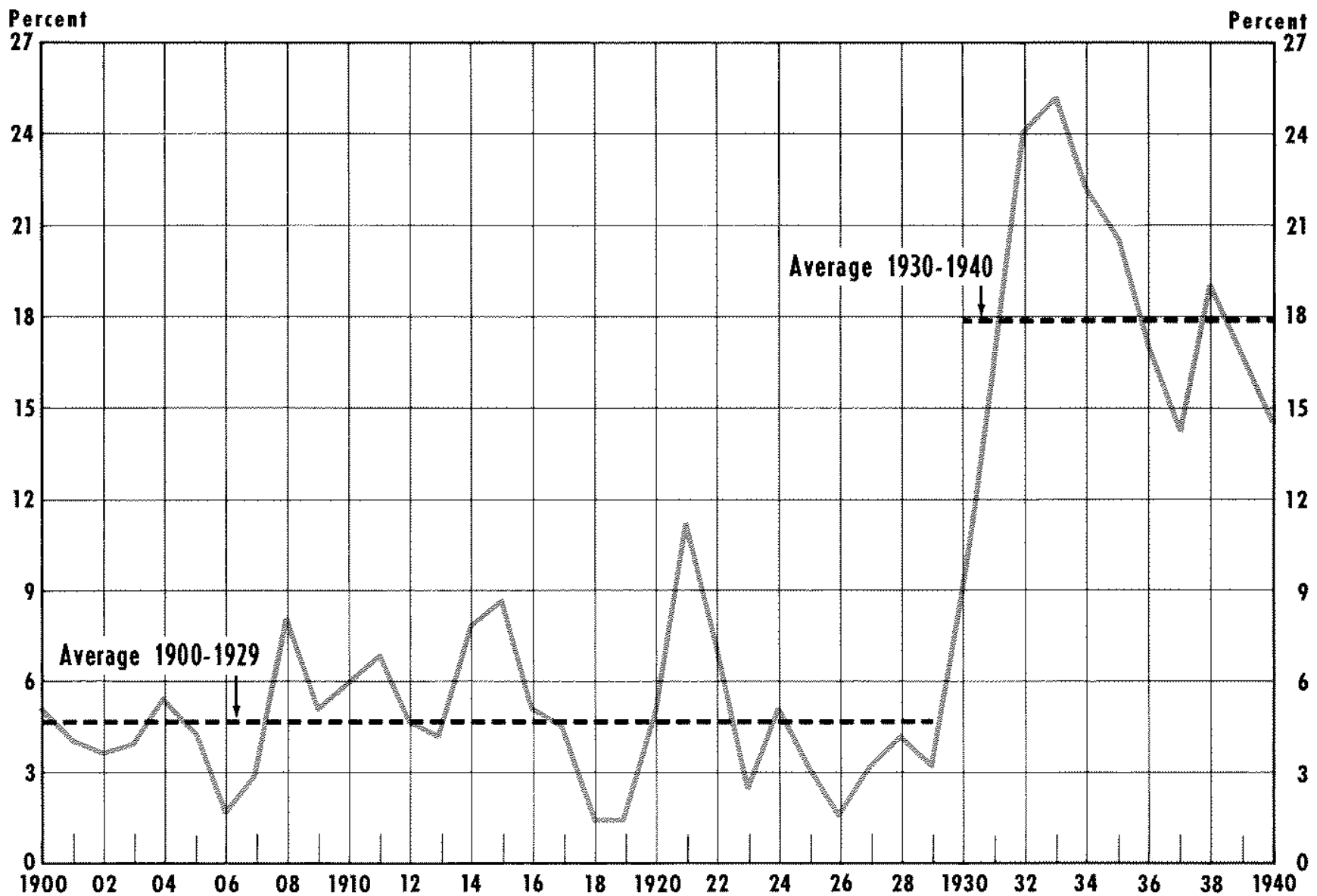

the labor force by 1933 , then declined fairly slowly to a level of about 15 percent in 1940 . During the 11-vear petiod from $1930-40$, it averaged about 18 percent. Charts 2 and 3 show real gross national product and the price level (as measured by the implicit GNP deflatory over the same period. Like chart 1 , these charts show a sharp economic contraction beginning in 1930. By 1933, real GNP had declined to about $\$ 140$ billion from its level of about $\$ 200$ billion in 1929 , while the price level fell by about 40 percent.

The sharpest recorded contraction in economic activity that occurred before this episode followed World War I (from 1918-21), and the sponsors of the full Employment Bill were notivated by the fear that the end of World War II and the re-entry of discharged war veterans into the civilian labor force would augur a return of the problems of the $1930 \mathrm{~s}$.
The data presented in charts 1-3 did not exist when the bill was debated in $1945 .^{5}$ As a result, the authors of the bill used unofficial estimates of unemployment for years prior to 1942 to bolster their arguments in favor of the bill's passage." These estimates were inserted into the hearings from a book by Henry wallace that was widely referred to in the popular press at that time?

It was not until August of 1942, when the task of estimating unemployment was transferred from the Works Progress Administration to the Census Bureau, that official definitions of "employed" and "unemployed" were developed and consistently applied in periodic surveys of the labor force. See Bancroft (1957), p. 66 and U.S. Department of Labor (1982), p. 3.

6Full Employment Act of 1945 (1945), p. 1103.

SSee Wallace (1945). 
Chatt 2

\section{Real Gross National Product}

Billions of dollars

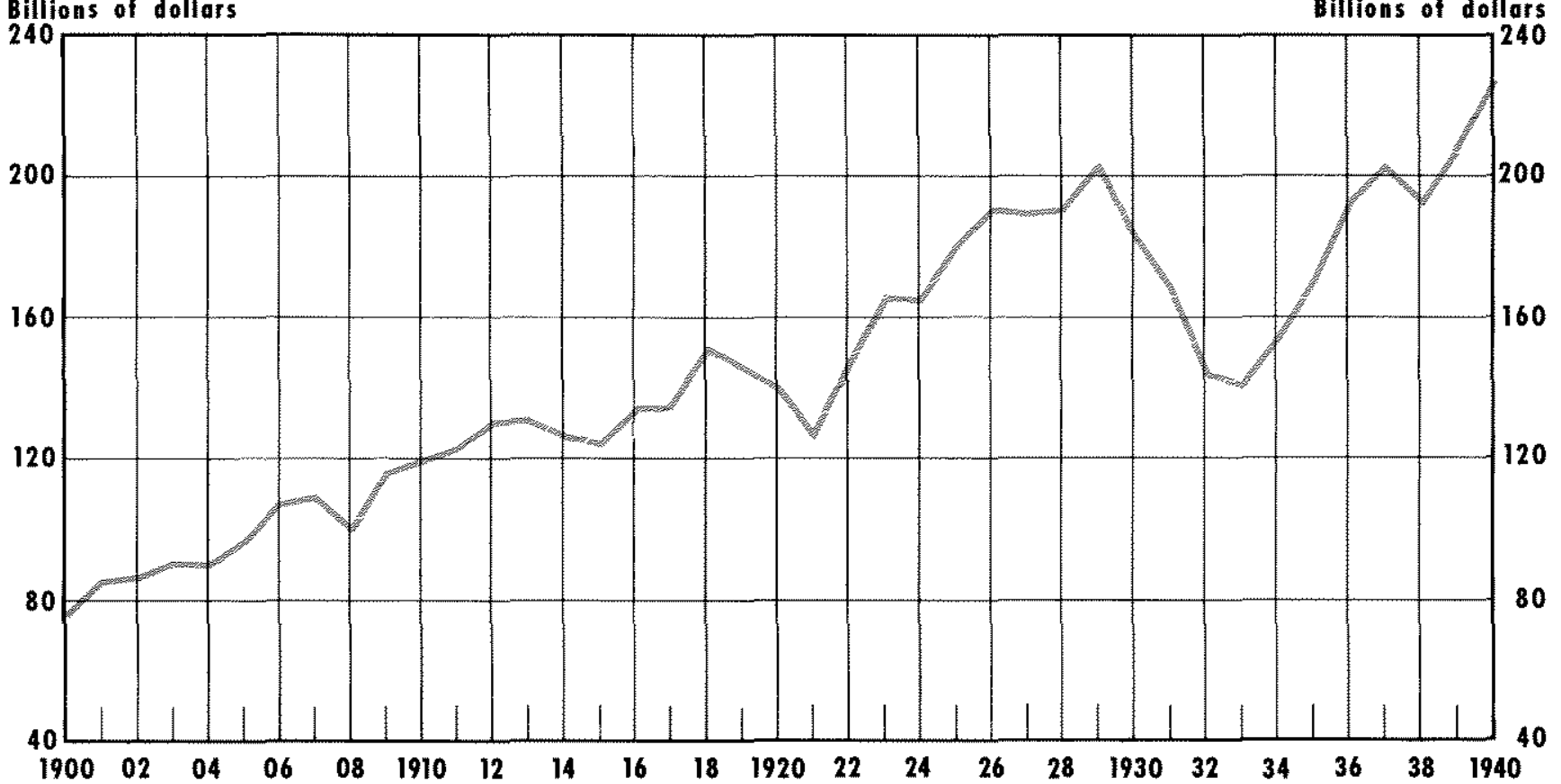

Wallace's data, which span the period 1900-44, are reproduced in chart 4 . The chat presents estimates of the labor force, the level of employment consistent with "full" employment, and the actual level of employment." The story told by Wallace's graph, which shows a large gap between full and actual employment during the 1930 s, is consistent with the more refined data shown in chart $1 . "$

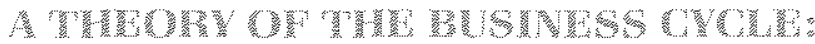 1...}

The sponsors of the Full Employment Bill were

W Wallace estimates full employment by subtracting an estimate of frictional unemployment from the labor force. See Wallace (1945). pp. $19-20$.

wallace (1945), pp. 20-22. Waliace attributed the abnomaly high level of unemployment to "the planlessness of the twenties" and suggested that the system of free enterprise in the United States survived only because of the "bold, courageous action of the Roosevelt New Deal" and then only by the narrowest of margins. influenced by the view of John Maynard Keynes. "He suggested that unemployment was the result of insufficient aggregate demand relative to the full employ. ment supply of output." Keynes argued that swings in aggregate demand generate business cycles with corresponding fluctuations in employment and unemployment. ${ }^{1 \pm x}$

While Keynes suggested a number of factors that could induce changes in aggregate demand, the one

toln the minds of both the sponsors and opponents, the legislation was considered an application of the theory "advanced by Lord Keynes. Stuart Chase, Sir William Beveridge, and Mr. Henry Wallace." Stuart Chase was a social scientist and the author of numerous popular books and articles concerning the Depression. Sir William Beveridge was best known as the chief architect of Britain's welfare state legislation that was enacted in the 1940s.

"See Keynes (1964), pp. 247-49 and 280-91. "We have shown that when effective demand is deficient there is under-employment of labour in the sense that there are men unemployed who would be willing to work at less than the existing real wage." p. 289.

${ }^{12} 2^{2}$ It is upon the fact that fluctuations tend to wear themselves out belore proceeding to extremes and eventually to reverse themselves, that the theory of business cycles having a regular phase has been founded." $t$ bid., p. 250. 
Chart 3

\section{Price Level}

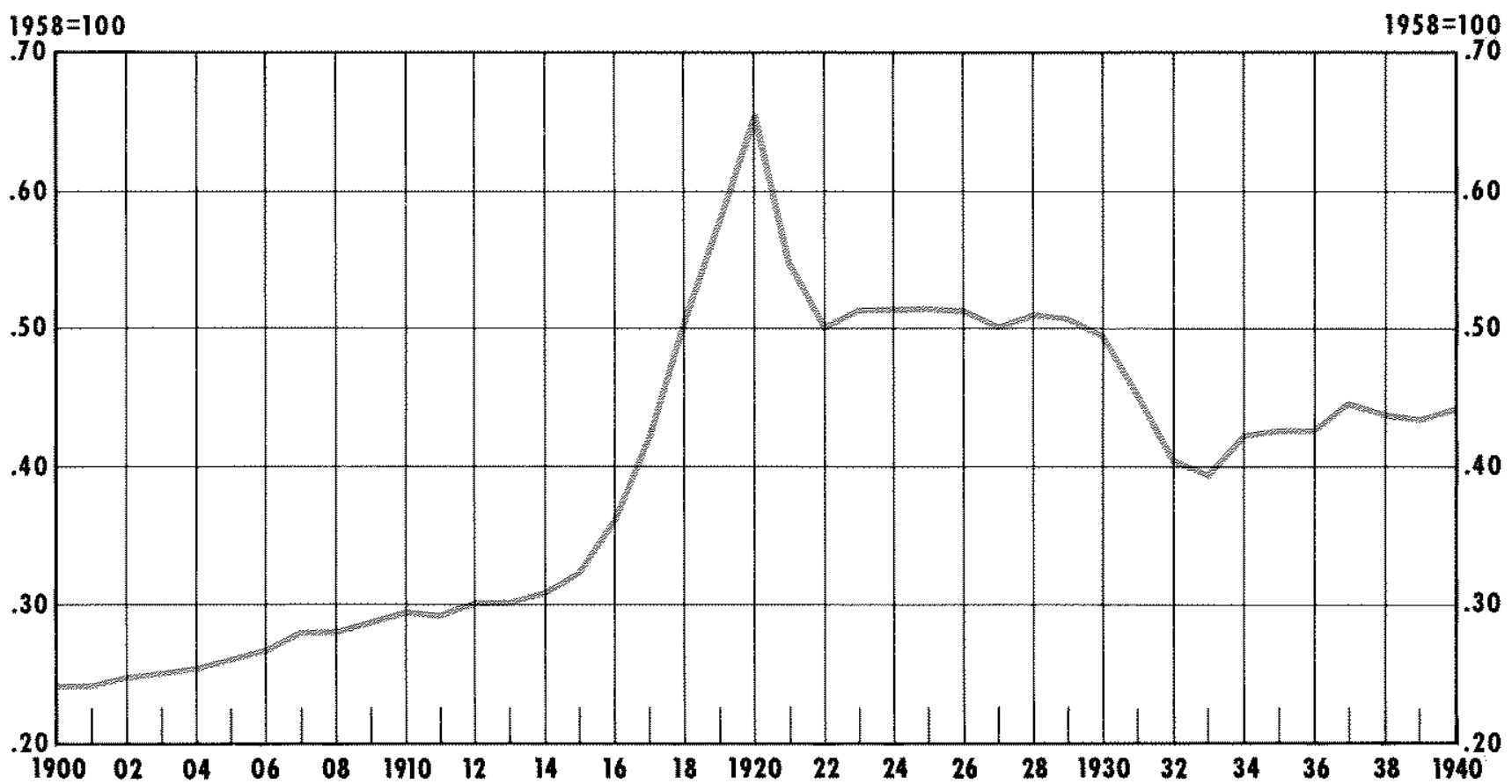

he believed contributed most strongly to generating business cycles was fluctuation in business investment." In large part, this fluctuation reflects changes in "the state of confidence concening the prospective yield" of available investment alternatives, which can change radically over time due to "the extreme precariousness of the basis of knowledge on which our estimates of prospective yield have to be made." \&4

Furthermore, activity on the london and Wall street stock exchanges amplified the effect of the changes in the state of confidence on real investment. Keynes suggested that these stock exchanges transformed the extremely important social process of directing capi

aSome of the other factors Keynes mentions are "the physical conditions of supply in the capitat goods industries, . . . the psychological attitude to liquidity and the quantity of money ..." Ibid., $p$. 248

14/bid., pp. 149,153,248,313,316 and 322. According to Keynes, this tendency for radicat change in the state of business confidence is accentuated by such things as the "day-to-day fuctuations in protis ... (that) tend to have an altogether excessive, . . . influence on the market"; "waves of optimistic and pessimistic sentiment"; the "antisocial ... feists of liquidity": and "the dark forces of time and ignorance which envelop our future." ibid., pp. 153-55. tal investment to its most profitable use "into a byproduct of the activities of a casino..." th while the sponsoms of the Full Employment Bill may not have accepted every "jot and tittle" of Keynes' analysis, they clearly believed that labor market conditions were too important to be left to the vagaries of a roulette wheel.

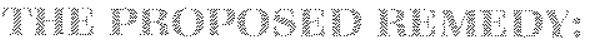

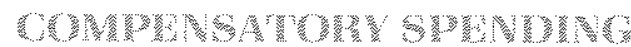

The initial draft of the proposed legislation wont under the title of the Full Employment Bill of 1945. This bill proposed to attack the problem of unemployment in two ways. Section 2(b) stated that "all Ameri cans able to work and desiring to work are entitled to an opportunity for useful, remunerative, regular, and full-time employment." In the view of the sponsors

T5/bid, p. 159.

${ }_{16}$ Assuring Full Employment in a Free Competitive Economy (1945), $\mathrm{p}$ 81. The proposed legislation used the words "are entitled to" rather than the word "right" but is is clear in the following subsection and in the debates and hearings that the sponsors intended to establish the opportunity to unlitime employment as a basic right of all Americans. See, for example, pp. $7-8$ and $71-80$. 


\section{Chart 4}

\section{Wallace's Estimates}

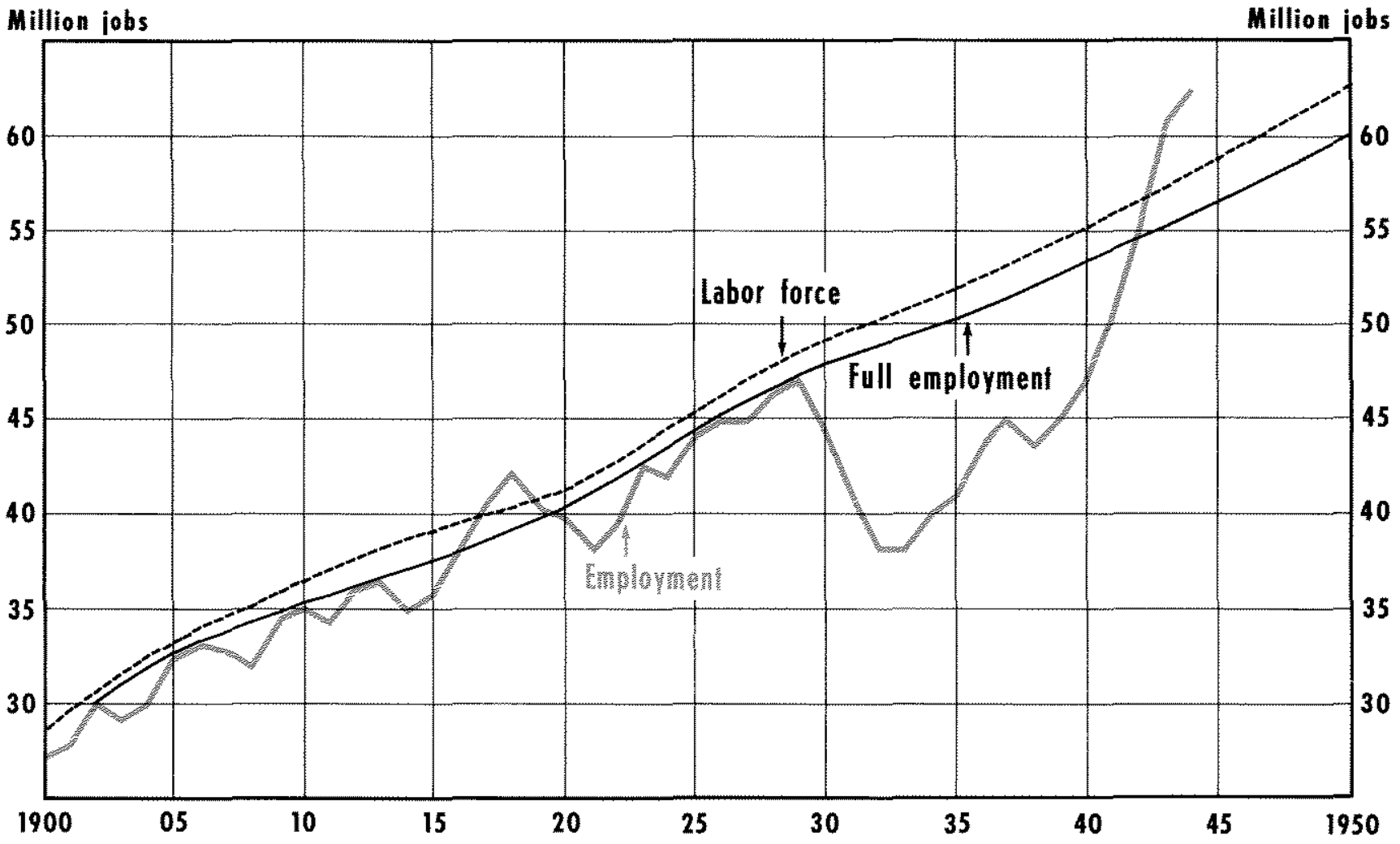

the conditions necessary for continuous full employment could not be expected from the system of private enterprise. Consequently, the bill placed the responsibility for the maintenance of fill employment on the federal government. Section $2(c)$ requires the federal government to "provide such volume of Federal investment and expenditure as may be needed ... to assure continuing full employment."

Section 3 laid out a formula for the federal govemment to follow in pursuing this goal. The formula required the President of the United States to submit a national budget to Congress at the beginning of each regular session. The budget was to contain a forecast of both the level of output necessary to generate full employment over the next year and the level of output that was likely to result if government did not intervene. If the projected level of output was less than the

${ }^{17}$ bid., p. 81. level necessary for full employment, the President was required to recommend legislation that would produce a big enough deficit in the federal government's budget to raise output to the full employment level. If the relationship between the two output forecasts were reversed, the President was required to recommend legislation that would result in a budget surplus big enough to reduce output to the full employment level. ${ }^{1 s}$ At the time, this method of stabilizing economic activity was called "compensatory finance."

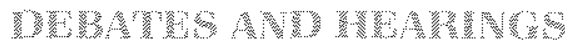

One of the important features of the draft legislation was that it put in place the machinery to apply the

18/bid., p. 82

"Assuring Full Employment in a Free Competitive Economy, Minority Views (1945), p. 4. See Keynes (1935), pp. 313-32 and 372-84. 
principle of compensatory finance on a continuous basis, year in and year out. The sponsors believed that a continuous application was necessary because they interpreted Wallace's data as indicating that high levels of unemployment were a natural consequence of free enterprise.

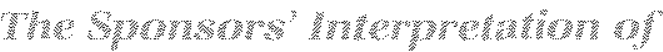

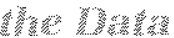

As mentioned, a striking feature of Wallace's data is the large and per'sistent gap between full employment and actual employment that occurred during the 1930 s (see chart 4). The gap averages about 18 percent of the labor force, indicating that a very serious economic problem existed during this period. Wallace, in his book, and the sponsors of the Full Employment Bill, during the hearings and debates, focused entirely on this gap.

From the viewpoint of the bill's sponsors, these data indicate that the system of private entepprise was prone to sizeable periodic disruptions. The congressional debates and hearings are filled with assertions that "the history of employment and production in the United States is a record of boom and bust. It is a recond of brief periods of growth and development culminating in peaks of prosperity that gave way to disastrous collapse:" or that "private enterprise, left to its own devices, cannot provide full employment and cannot eliminate periodic mass unemployment and economic depressions." "\#1

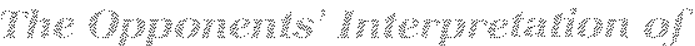 Whe}

To opponents of the bill, the data suggest that employment behavior during the 1930 s was perverse by past standards. Indeed, the ' 30 s are noteworthy because the behavior of unemployment during these years was so unusual. ${ }^{2 t}$

Chart 4 shows that the level of actual employment remained very close to the estimate of full employment over the first 30 years of the sample. There were sharp increases in 1908, 1914, and 1921; and the gap was negative during America's involvement in World

2afull Employment Act of 1945 (1945), p. 1181. An addition, see Assuring Full Employment in a Free Competitive Economy (1945), pp. $2,3,9,12,20,21,45$ and 47

21 Why the ' 30 s were unusual is still debated and beyond the scope of this paper. The interested reader is reterred to Alchian and Allen (1977) pp. 467-80, especially page 477, and Friedman and Schwartz (1963)
War 1.2 These gaps, thowever, quickly vanished so that actual employment was never much different than full employment for any appreciable length of time.

Opponents of the bill disputed claims that the conditions experienced in the 1930s were a natural consequence of free enterprise ${ }^{33}$ While agreeing that business cycles are inevitable, they argued that economic forces operate to move the economy in the direction of fill employment. The opponents suggested that compensatory spending should be applied only in the event of an extreme contraction to limit its depth and duration. s $^{2}$

In addition to this dispute, the debate focused on three specific points: 1) whether the requirement to maintain continuous full employment and price level stability was feasible; 2) whether the govemment could generate the necessary forecasts; and 3 ) whether the right to employment should be written into law.

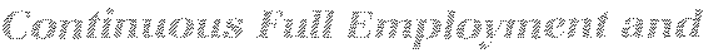

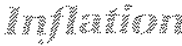

The opponents thought business cycles were inevitable, and their consequences, in the form of temporarily reduced employment, could not be legislated away. They argued that business cycles were symptoms of the adjustment process to, say, a major change in consumer demand in favor of some goods but against others, a change that causes phoduction costs to rise for some goods but fall for others, or a change in aggregate supply like an unusually good of bad harvest. Any of these changes results in a movement of resources (including laborl from one job to another. The adjustment takes time to complete and, in the interim, unemployment increases.

The proposed bill required the federal govemment to retard these necessary adjustments. While the opponents conceded that "Government spending oan for awhile create full employment as it did during the war $^{\prime 2,2,}$, they objected to the policy because it reduces

\footnotetext{
Wallace attributes this anomaly (a negative gap) to the war years. See Wallace (1945), p. 10. Technically, the negative gap occurs because Wallace does not define the labor force as the sum of employed and unemployed workers.

nsome suggested that the New Deal legisiation of this period had discouraged private investment and contributed to the severity and length of the Depression. Full Employment Act of 1945 (1945), p. 1137 .

${ }^{2}$ Assuring Full Employment in a Free Competitive Economy (1945), p. 21.

${ }^{25}$ Assuring Full Employment in a Free Competitive Economy, Minority Views (1945), p. 5
} 
unemployment in the short run by moving it to the long run and does so at the cost of higher inflation. ${ }^{3 *}$

The sponsors of the bill conceded this point but argued that the resulting inflation would be insignificant in comparison to a return to high levels of unemployment and the social unrest that would inevitably follow in its wake.

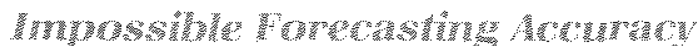

The bill required the president to estimate the number of jobs necessary for full employment, the value of production consistent with full employment, and the value of production that would occur in the absence of any new federal compensatory spending program. In the opinion of the opponents, successfully completing such a task 16 to 18 months in advance of the events was virtually impossible. They pointed out that the estimates would depend on the prevailing price level, the kinds of goods (and hence, jobs) making up aggregate production, and average wage vates. They asked Congress to consider "how wrong any estimate for 1930 would have been, if made in 1929 ."

The defense mustered against this criticism was that the bill required forecasts based on "current trends" in the data. Opponents pointed out that maintaining continuous full employment required the discovery of deviations from trend as well as breaks in the trend before they occurred, Extrapolating current trends would not do the job.

\section{W}

No provision of the bill received more attention during the debates than section 2 b-cl, which extended to all able Americans the right to an opportunity for full-time employment. Extending this right meant that the federal government would become responsible for assuring that enough jobs were avail-

\footnotetext{
26/bic., p. 5. "The adoption of such a policy (compensatory spending), , would result in continued Federal spending over many years, causing an inflation of prices and an artificial boom, and then the very depression and unemployment we are trying to avoid."

${ }^{27} / \mathrm{bid}, \mathrm{p}$. 3. One of the most forceful criticisms of the forecasting fequirements was presented during the public hearings by Elisha $M$. Friedman who suggested that, "Forecasting economic conditions 16 months ahead is a task for gods, not mortals ... Look over the Department of Agriculture forecasts in the spring of the final crop for the year. Look at the ... complete tallure of the ICC to forecast economic conditions or earnings, ... What Government forecasts have ever been ... equal to the average of blind chance? How much Government toresight is revealed in the Pearl Harbor report or in our prewar policy?" Full Employment Act of 1945 (1945), pp. 1128-29.
}

able Opponents objected to this provision because: 1) the bill made no provision for enforcing the right; 2 ) it would lead people to expect more than the government could possibly deliver; and 3 ) the provision is socialistic and alien to the basic principles of the United States. ${ }^{29}$

During the debates, supporters conceded that, "the statutory enunciation of the right to an opportunity for employment does not imply redress through the courts." 30 Rather people who believed they were pre. vented from exercising this right could petition the government to improve its economic policy or obtain a change in government through the regular election process. Opponents argued that the inclusion of this right in the bill, at best, extended an empty promise to the electorate and led them to expect more than the government was willing or able to deliver. At worst, any attempt to enforce the right would be incompatible with the fundamental objective of the bill as well as with democratic institutions. ${ }^{33}$

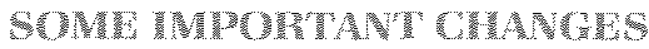

The debates resulted in significant changes between the bill as it was initially reported and the legislation that was finally enacted by Congress (see shaded insert on the next page). For example, amendments succeeded in eliminating the declaration of the right to an employment opportunity, the federal govemment's responsibility to assure continuing full employment, and the requirement to submit a budget based on the principle of compensatory finance. In particular, section 2 of the final version states that it is the intention "of the Federal Government ... to promote maximum employment, production, and purchasing power." Thus, the actual legislation is a state-

\footnotetext{
${ }^{2}$ Of course, scarcity assures everyone of a job at a sufficientiy low wage. The rub came because the wage considered to be "remunerative" was $\$ 2,000$ per year which was the average annual income of private nonagricutural workers at that time.

${ }^{29}$ As the Kiplinger Washington Letter once noted, "Jobs for everyone able and willing to work leaves out a tot of people."

so Assuring Full Employment in a Free Competitive Economy (1945), p. 27.

${ }^{31}$ Assuring full Employment in a Free Competitive Economy, Minority Views (1945), pp. 4-5, 27. This criticism was discounted by Sen. Thomas of Utah, a spokesman for the bill. He reminded detractors "that the basic difference between the American constitutionat concept (and totalitarian regimes) ... is that in America we have all the time the welfare of the individuat person in mind." The senator's argument cals to mind Danie Webster's observation that "There are men in all ages who mean to govern welt, but they mean to govern. They promise to be good masters, but they mean to be masters."
} 


\section{Important Differences Between the Bill and the Act}

The following sunmarizes some of the more inportant differences between the full Employment Bill as reported by the Banking and Currency Com

\section{The 1945 Bill}

\section{Section 1}

This Act may be eited as the Full Employment Aet of 1945.

\section{Section 2}

b) 'All Americans. are entitled to an oppontanity for useful, remunerative, regular, and filltime employment.

c) In order to assure the free exercise of the right to an opportunity for employnent. , the Federal Government has the responsibility to assure continuing full employment, that is, the existence at all times of sufficient employment opportunities for all Americans. . ?'

d) To that end the Federal Government shall, . provide such volume of Federal investment and expenditure as nay be needed, . . to assure continuing full employment.

\section{Section 3}

The President shall transmit 10 Congress . a general program purstiant to section 2 f for assur ing continuing full employment .. "?

ment of intention rather than a requirement to act Furthermore, it indicates that the government is concerned about more than just the level of employment on occasion, the government may wish to pursue an economic policy that results in less than full employment but greater price stability, for example. Moreover, the final version does not contain the requirement to "provide such volume of Federal investment and expenditure as may be needed / to maintain continuing full employment]." This provision had been the "heart and soul" of the bill as initially reported.

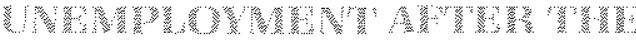 Mran}

Unemployment in the United States remained at fairly low levels for about 20 years following the $\mathrm{Em}$ - mittee and the Employment Act of 1946 that was approved on February 20, 1946 . Ilalics are added to emphasize deletions or changes in wording.

\section{The 1946 Act}

\section{Section 1}

"This Act may be cited as the Employment Act of 1946:"

\section{Section 2}

"The Congress hereby declares that it is the contimuing policy and responsiblity of the federal Govermment, to promote maximum employment, production and purchasing power.

\section{Section 3}

The President shall transmit to the Congress. a program for carrying out the policy declared in section 2 ,

ployment Act (see chart 5). The unemployment rate averaged 4.6 percent from $1950-70,3$ 'This average was just about the same as the average for $1900-29$ which was about 4.5 percent. Business cycles, of course, occurred in both periods and account for fluctuation in the unemployment rate around its average. After 1970, however, the unemployment rate began to rise. By 1975, it had reached a level of more than 8 percent. An unemployment rate this high had not been experienced since the 1930s and it rekindled many of the fears that had motivated the 1946 legislation.

\footnotetext{
32Whether this relatively low average rate was simply fortuitous or the result of the legislation is beyond the scope of this paper.
} 
Chart 5

\section{Unemployment Rate}

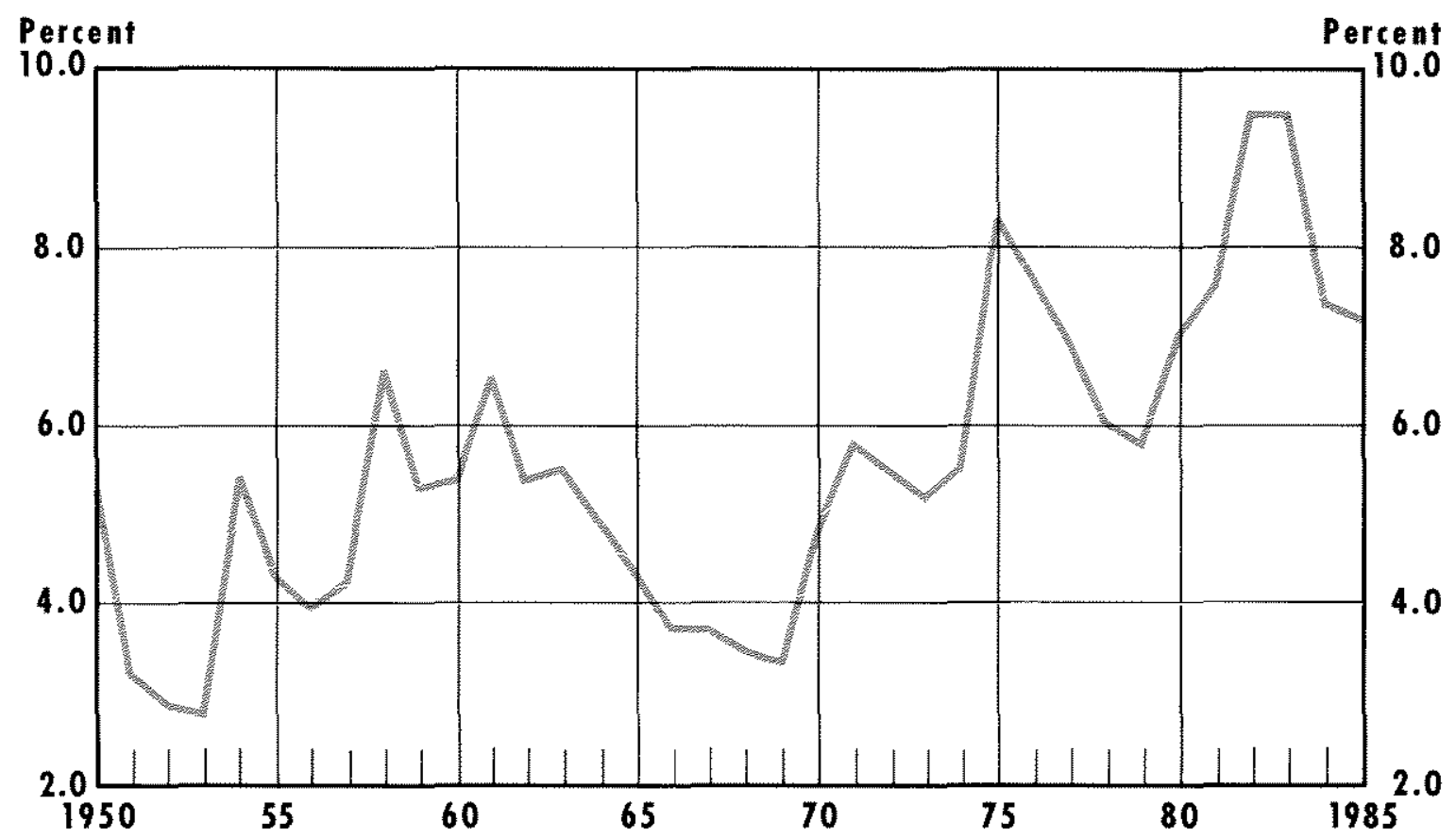

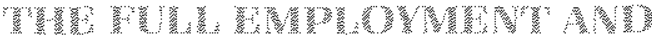

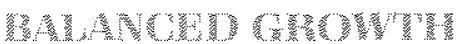

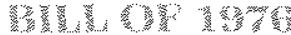

Thirty years after passage of the Employment Act of 1946, Sen. Hubert H. Humphrey and Rep. Augustus F. Hawkins introduced the Full Employment and Balanced Growth Bill of 1976 . The core of this bill was a carbon copy of the initially proposed Full Employment Bill of 1945 .

The 1976 bill resurrected "the right of all adult Americans able, willing, and seeking work to opportunities for useful paid employment at fair rates of compensation." It required the president to establish "annual numerical goals for employment, production, and purchasing power" and to submit a budget containing a "level and composition of Federal expenditures, measured against estimated capabilities at full employment and production, necessary to support the annual economic goals proposed in section 3 and to support the Full Employment and Balanced Growth Plan .... In addition to this core, the bill

${ }^{33}$ Full Employment and Balanced Growth Act of 1976, pp. 7-10, and 15. contained provisions regarding the coordination of monetary and fiscal policies, economy in government, anti-inflation policy, regional employment policy, youth employment policy and income maintenance; it also established an Advisory Committee on Full Enployment and Economic Growth.,

The legislative process was less kind to the 1976 bill than it was to its 1945 forerunner. One critic of the bill remarked that the seedling of the unemployment goal had grown into an "unmanageable Christmas tree," an "unworkable monster" that deserved to be chopped down. The bill was debated for more than two years and, like its foremunner, was stripped of its substantive provisions when President Carter signed it on October 27,1978 (see the shaded insert on the next page for the main provisions of the Full Employment and Balanced Growth Act of 1978).

${ }^{34} \mathrm{~A}$ comment of Raymond Moley's regarding the profiferation of conflicting goals in some New Deal fegistation seems pertinent at this point. Moley wrote that "to look upon these policies as the result of a unified plan was to believe that the accumulation of stuffed snakes, baseball pictures, school flags, old tennis shoes, geometry books, and chemistry sets in a boy's bedroom could have been put there by an interior decorator." Moley (1939). 


\section{The Full Employment and Balanced Growth Act of 1978}

The following is a condensed list of the main provisions of the Humphrey/Hawkins Act.

\section{Title I - National Goals and Priorities}

1) Declares a national policy of promoting full employment increased real income balanced growth, a balanced federal budget, growth in productivity, an improved balance of trade, and price stability.

2) Declares a policy of primary reliance on the private sector for accomplishing the above economic goals.

$3)$ Encourages the adoption of fiscal policy that would reduce federal spending as a percent age of GNP.

4) Requires the President to set budgetary goals so as to achieve an unemployment rate of not more than 3 percent among persons aged 20 and over, and 4 percent for persons 16 and over by 1983

5) Requires the president to set a budgetary goal of reducing the rate of inflation to 3 percent by 1983 Fumhemore, once the goal set in 4 above is achieved, the President is required to set a goal directed at reducing inflation to 0 percent by 1988 .

6) Allows the President to modify the timetables for achieving the goals set forth in 4 and 5 above.

7) Requires the Federal Reserve Board to repoit to the Congress twice a year on its monetary policies and their relationship to the goals of the act:

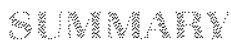

The legislative proposal advanced in the Full Employment Bill of 1945 was motivated by the severe Depression of the 1930 s and the fear that this condition would return with the demobilization following World War II. Many advocates of the legistation were convinced that the system of private enterprise was prone to sizeable periodic disruptions caused by the ertatic behavior of business investment. As initially

\section{Title II - Structural Economic Policies}

1) Permitted the President to establish "reser" voirs of public employment, if he found that other policies were faling to achieve full employment goals

2) Required that any reservoir jobs be useful and in the lower ranges of skill and pay, be targeted on individuals and areas with the worst unemployment problems and be set up so as not to draw workers from the private sector.

\section{Title II - Congressional Review}

1) Establishes procedures for Congressional re view of Federal Reserve Boand goals and policies.

2) Gives Congress the option of determining when the full employment goal could be reached should the President declare that the goal could not be met by 1983 .

\section{Title $\mathrm{N}$ - General Provisions}

1) Prohibits disctimination on account of $\mathrm{sex}_{\text {, }}$ race, age religion or national ongin in any program under the bill.

2) Provides that workers in reservoir jobs be given equal pay for equal work, but not less than the federal minimum wage. proposed, the legislation required the federal government to intervene to smooth out the business cycle. The legislation was based on the principle of compensatory finance which argued, for example, that a projected slump in economic activity could be offset by rumning a sufficiently large deficit in the federal budget.

The initial proposal did not fare well in the debates. Various people argued that business cycles reflected the process of redirecting resources (including labor) 
brought about by major shifts in the relative demand or supply of various goods and services. In their opinion, the government's responsibility should be limited to the relief of destitution which frequently could be accomplished more adequately and cheaply in ways other than maintaining employment in jobs of lesser value. ${ }^{35}$ Others argued that the application of compensatory finance required forecasting accuracy that could not possibly be achieved. They pointed out that the business slump that began in 1930 was not forecast in 1929 and that existing government agencies responsible for forecasting economic conditions produced results that were indistinguishable from random chance.

The Employment Act of 1946 that was approved by Congress differed markedly from the Full Employment Bill of 1945. As approved, the act recognized both high employment and price level stability as important economic objectives. Furthemore, the requirement to apply the principle of compensatory finance, the cenm terpiece of the 1945 proposal, was stripped away.

The Humphrey/Hawkins Bill of 1976 attempted to revive the main provisions of the 1945 bill. Congress, however, had become no more sympathetic in the intervening 30 years. As in 1946, they extracted the legislation's teeth before approving it and created an "unworkable monster" by loading the bill with an agglomeration of conflicting policy statements. In the end, the bill was hailed as a legislative monument to Hubert Humphrey, who had died in January 1978. Apart from this, and the expression of congressional sentiment regarding a vast array of economic problems, the legislation was not expected to produce much of substance.

Debates over the economic consequences of the 1946 employment act continue to this day. However, many would agree with the assessment given by Avin Hansen in a collection of papers celebrating the tenth anniversary of the 1946 act. In his opinion, public: exposure to policy debates stimulated by the Economic Report of the President and the Hearings before the Joint Committee, both of which are required by the legislation, have had the effect of rasing the level of economic literacy in the United States. As for the real economic consequences of employment legislation, he suggests that "there are as many economic opin- ions worthy of consideration as there are competent economists." 3 it

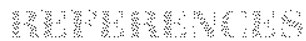

Alchian, Armen, and William R. Allen. Exchange and Production: Competition, Coordination, and Control, 2nd ed. (Wadsworth, 1977) pp. 467-80.

Assuring Full Employment in a Free Competitive Economy. Report from the Commitiee on Banking and Currency, 79 Cong., 1 Sess. (Government Printing Office, Seplember 1945).

Assuring Full Employment in a Free Competitive Economy, Minority Views. Report from the Committee on Banking and Currency, 79 Cong., 1 Sess. (Government Printing Office, September 1945).

Bancroft, Gertrude. "Current Unemployment Statistics of the Census Bureau and Some Alternatives," in The Measurement and Behavior of Unemployment (Princelon University Press, 1957), pp. 63-119.

Darby, Michael R. "Three-and-a-Half Million U.S. Employees Have Been Mislaid: Or, an Explanation of Unemployment, 19341941," Joumal of Political Economy (February 1976) pp. 1-16.

Employment Act of 1946, 79 Cong., 2 Sess. (S. 380), Public Law 304.

Fellner, William J. "The Balancing of Objectives Under the Employment Act of 1946," in The Employment Act Past and Future (National Planning Association, 1956) pp. 87-91.

Friedman, Milton, and Anna Jacobson Schwartz. A Monetary History of the United States 1867-1960 (Princeton University Press, 1963) pp. 299-545.

Full Employment and Balanced Growth Act of 1976 , Committee on Labor and Public Welfare, S. 50, 94 Cong., 2 Sess. (Government Printing Office, 1976).

Fulf Employment and Balanced Growth Act of 7978 , Public Law 95-523 (H.A. 50), October 27, 1978.

Fulf Employment Act of 1945, Hearings Before a Subcommittee of the Committee on Banking and Currency, United States Senate, 79 Cong., 1 Sess. (Government Printing Office, September 1945).

Hansen, Alvin H. "The Reports Prepared Under the Employment Act," in The Employment Act Past and Future (National Planning Association, 1956) pp. 92-97.

Harris, Ralph. "Where Does Unemployment Come From?" in Job 'Creation' - or Destruction? (Institute of Economic Affairs, 1979) pp. $5-9$.

Historical Statistics of the United States Colonial Times to 1970 , U.S. Department of Commerce, Bureau of the Census (U.S. Government Printing Office, 1975), pp. 121-22 and p. 126 .

Keynes, John Maynard. The General Theory of Employment, interest and Money (Harcourt, Brace and Company, 1935).

Lebergott, Stantey. "Annual Estimates of Unemployment in the United States, 1900-1954," in National Bureau of Economic Research The Measurement and Behavior of Unemployment (Princeton University Press, 1957) pp. 213-38.
${ }^{35}$ Assuring Full Employment in a Free Competitive Economy (1945), p.
25 .
${ }^{36}$ Hansen (1956), p. 97 
Moley, Raymond. After Seven Years (Harper, 1939) pp. 369-70.

Romer, Christina. "Spurious Volatility in Historical Unemployment Data," Journal of Political Economy (February 1986), pp. $4-37$.

Summary of Federal Agency Reports on Full Employment Bill, Report to the Committee on Banking and Currency, 79 Cong., 1 Sess. (Government Printing Office, July 1945).
Tobin, James. "The Interdependence Between an Effective Stabilization Policy and the Attitudes of Labor," in The Employment Act Past and Future (National Planning Association, 1956, pp. 114m 18.

U.S. Department of Labor, Bureau of Labor Statistics, BLS Hand book on Methods (December 1982), pp. 3-11.

Wallace, Henry A. Sixty Million Jobs (Simon and Schuster, 1945) pp. 8-22. 